\title{
The Electrochemical Behavior of Titanium Improved by Nanotubular Oxide Formed by Anodization for Biomaterial Applications: A Review
}

\author{
A. A. AL-SWAYIH \\ Department of Chemistry, College of Science, Princess Nora Bint Abdul Rahman University. \\ ${ }^{*}$ Corresponding author E-mail: aswayih@yahoo.com \\ http://dx.doi.org/10.13005/ojc/320602
}

(Received: March 03, 2016; Accepted: October 15, 2016)

\begin{abstract}
Titanium oxide nanotube is gaining prominence in many applications like solar energy, sensors, catalyst and biomaterials. In this paper, we briefly review the electrochemical behavior of titanium oxide nanotube prepared by anodization in simulated body fluids. The electrochemical behavior of $\mathrm{TiO}_{2}$ nanotube depends on its morphology and surface properties. When titanium oxide nanotube formed by anodization, these surface properties are depending strongly on two factors, the parameters of anodization process and the conditions of employed electrolyte. These factors must be chosen in correct manner to optimized titanium oxide nanotube with desired properties for specific application.
\end{abstract}

Keywords : Titanium oxide nanotube, anodization, biomaterials, corrosion.

\section{INTRODUCTION}

\section{General}

Titanium and its alloys are exploited in several technological fields ranging from aerospace and chemical industries to bone implant materials, because of their excellent properties and efficient performance in widespread applications ${ }^{1,2}$. They are used in photo catalysis ${ }^{3}$, self-cleaning processes, solar cells, fuel cells, catalysis, gas sensing devices, semiconductors doping, biomedical, interference coatings, and manufacturing optical devices ${ }^{1}$.
The variety of the applications of $\mathrm{Ti}$ is attributed to its excellent corrosion resistant, light weight ${ }^{4}$, low elastic modulus and biocompatibility'. The high and remarkable corrosion resistance is attributed to a very stable passive oxide film formed on its surface when exposed to the air or water ${ }^{2,5}$. The self-healing nature and compactness of the titanium oxide film make it suitable for many hostile environments ${ }^{1}$.

\section{Titanium in biomaterials}

In biomedical devices, selecting materials for different components depends especially on 
several factors. First, the implant materials must possess an excellent biocompatibility, excellent corrosion resistance and appropriate mechanical properties $^{6}$. Low elastic modulus is required to be close to that of a human bone, in order to transfer the adequate mechanical stress to the surrounding bone $^{7}$.

Moreover, the surface of biomaterials play an extremely important role in the response of artificial medical devices to the biological environment. When they have been implanted into the human body, a series of interactions occur between the surface of biomaterials and the biological environment. Thus, their surface characteristics such as surface morphology, microstructure, composition, and properties can determine the efficiency of artificial implants ${ }^{8}$.

In the field of medicine, titanium is well established as a biomaterial for bone anchorage and in soft tissues, e.g. in pacemakers, neurological implants, and metabolic sensors ${ }^{9-11}$ (fig.1). The biological, mechanical and physical properties of titanium and its alloys play significant roles in the longetivity of the prostheses and implants ${ }^{13}$.

The layer of titanium dioxide $\left(\mathrm{TiO}_{2}\right)$ covered titanium surface is believed contribute to its overall biocompatibility ${ }^{14-16}$. This layer with approximately 5 $\mathrm{nm}$ thickness forms spontaneously in air or water and exhibits favorable thermodynamic properties, and low ion formation and electrical conductivity in the physiological environment ${ }^{5}$. The stability of the titanium oxide film depends strongly on its composition, structure and thickness ${ }^{17}$.

Moreover, titanium oxide exhibits unique semiconductor-like properties that allow for the surface to change from $\mathrm{Ti}^{4+}$ to $\mathrm{Ti}^{3+}$, which make it ability to inhibit reactive oxygen species involved in the inflammatory response ${ }^{18-20}$. Due to the semiconductor- like properties of $\mathrm{TiO}_{2}$, it can acts as an electron donor or acceptor, and thereby actively participate in catalytic reactions with biologically relevant radicals ${ }^{4}$.

\section{Importance of titanium oxide nanostructure}

As bone is alive, and in order to prevent loosening and inflammation when an implant inserted close to it, an implant must be accepted by the bone cells, and must be able to bond to and grow on it. The surface of an implant can be modified to optimize its properties and to maximize its bioactivity when interfacing with natural tissue. The surface treatments or modifications methods can enhance the biological characteristics of implants by adding material with desired properties, changing the composition or removing unwanted material from the implant surface. These methods can be classified into four categories:

(a) Mechanical surface modifications like machining, grinding, polishing and blasting.

(b) Physical surface treatments include thermal spraying, physical vapor deposition, ion implantation and deposition, and glow discharge plasma treatment.

(c) Chemical surface modifications include chemical treatment (acid, hydrogen peroxide, alkaline), anodic oxidation, the sol-gel process and chemical vapour deposition.

(d) Biochemical surface modifications.

A number of techniques have been specifically introduced for titanium and titanium alloys, such as silanized titania, photochemistry, self-assembled monolayers, protein resistance and protein immobilization ${ }^{21-24}$.

Another suggestion to improve the biocompatibility of titanium and its alloys, is to use two scale surface modification, the first is nano-scale for bioactivity of the implant, and the second is microscale for osteoblast adhesion ${ }^{25}$.

A nanometre $(\mathrm{nm})$ is defined as the millionth part of a millimetre $\left(10^{-9} \mathrm{~m}\right)$. The nanotechnology based on the fact that new functionalities or properties result from the nanoscale character of the components. New properties and/or functionalities can be related to scratch resistance, colourfulness, transparency, conductivity, strength etc, which result from the altered ratio of surface atoms to volume atoms and from the quantum-mechanical behaviour ${ }^{26}$.

Recently, many researchers found that the formation of nanotube oxide surfaces on the native oxide resulted in very strong reinforcement of the bone response $e^{25,27-31}$. When titanium oxide surface 
tubes with nanoscale dimensions formed, the bioactivity of the implant improved and enhanced osteoblast adhesion on the surface ${ }^{32}$. The high surface area of titanium oxide nanotube and its ability for cell interlocking promote bonding to bone ${ }^{21,33,34}$.

Nanotubes fabricated on implant material surfaces not only provide great potential in promoting cell adhesion, but also in proliferation and differentiation. Moreover, nanotubes can offer the possibility of bacterial infection control by loading the tubes with antibacterial agents. However, studies were conducted to establish the optimum nanotopography for favourable cell response, and the optimum sizes of nanotubes for recognition and adherence by the sensing element of a bone cell ${ }^{21}$.

In vitro studies on the titanium oxide nanotube showed that nanotubular surface provides a favorable template for the growth of bone cells. Moreover, the cells cultured tests on the nanotubular surfaces showed higher adhesion, proliferation, alkaline phosphate activity and bone matrix deposition compared to those grown on smooth titanium surfaces. From in vivo studies, the biocompatibility results suggested that nanotubular titania does not cause chronic inflammation or fibrosis ${ }^{35}$.

Titanium oxide nanotube have attracted extensive attention due to their large surface area, low electron recombination and charge-transport properties, and are considered to be superior chemical materials because they form onedimensional channels for carrier transport. They are of considerable interest for applications in the field of photocatalysis ${ }^{36}$, water photolysis ${ }^{37}$, remediation of organic pollutants ${ }^{38}$, gas sensors ${ }^{39}$, solar energy cells $^{40}$, a promising role for biomaterials ${ }^{2}$ and corrosion resistance ${ }^{41}$.

\section{Anodization as preferred method to forming nanostructure}

There are a variety of preparation methods that have been used to fabricate titanium oxide nanotubes such as template synthesis ${ }^{42}$, sol-gel methods ${ }^{43}$, hydrothermal synthesis ${ }^{44}$, evaporation ${ }^{45}$, ion-beam synthesis $\left[{ }^{46}\right.$ and anodic oxidation ${ }^{47}$.
Among these, electrochemical anodization is widely used, due to its simplicity, cost effective technique, controllable and reproducible. It is also possible to control the size and the shape of nanotubes to the desired dimensions. In addition, titanium oxide nanotubes layer prepared by this method is strongly adherent on the substrate, which is very important for many practical applications ${ }^{2,48}$.

A comparison of three methods, the assisted-template method, electrochemical anodic oxidation and hydrothermal treatment, along with their advantages and disadvantages was made in previous review ${ }^{12}$. Titanium oxide nanotubes with ordered alignment and high aspect ratio had been produced by using anodization ${ }^{12,21,49}$.

In anodization process, the self-organized nanotubular titanium oxide can be produced by using electrolytes containing fluoride, such as $\mathrm{HF}$ electrolytes, chromic acid-HF mixtures, $\left(\mathrm{NH}_{4}\right)_{2} \mathrm{SO}_{4}$ $\mathrm{NH}_{4} \mathrm{~F}$ mixtures, $\mathrm{H}_{2} \mathrm{SO}_{4}-\mathrm{HF}$ mixtures and $\mathrm{H}_{3} \mathrm{PO}_{4}-\mathrm{NaF}$ mixtures $27,28,31,32,50,51$.

The anodization process can be conducted by using an electrochemical cell consisting of two electrodes, one is platinum ( or graphite) as a counter electrode and the second is the working electrode representing the anode of the cell, as shown in fig, 2 . A DC power source was employed for the purpose. Before anodization, the sample surface must be prepared by appropriate methods, i.e. employing polishing papers of different grades and ultrasonic cleaning. The anodization was performed by increasing the potential of the sample from $0 \mathrm{~V}$ to the desired potential with a suitable scan rate, followed by holding the sample in the potential for specific time at chosen temperature ${ }^{27,51,52}$. For example, fig. 3 presented titanium oxide nanotubes formed on titanium metal by anodization in $1 \mathrm{M}$ $\mathrm{Na}_{2} \mathrm{SO}_{4}+0.5$ wt. \% NaF at $20 \mathrm{~V}$ for $30 \mathrm{~min}^{53}$.

It should be possible to control the nanotube size and morphology for the desired application by controlling the electrochemical conditions, i.e. applied voltage, anodization time, and the solution conditions, i.e. composition of the electrolyte and fluoride ions concentration, $\mathrm{pH}$, water content in the electrolyte and its temperature ${ }^{12,51-57}$ 
The first time of the titanium oxide nanotube arrays generation was grown in $\mathrm{HF}$ electrolytes or acidic HF mixtures ${ }^{58-60}$. These layers have a limited thickness about 500-600 nm. By taking into account the importance of the $\mathrm{pH}$ gradient within the tube ${ }^{7}$, and using buffered neutral electrolytes that containing $\mathrm{NaF}$ or $\mathrm{NH} 4 \mathrm{~F}$ instead of $\mathrm{HF}$, the thickness of the self-organized nanotube titanium oxide layers will increase more than 2 micrometer ${ }^{61-64}$. The third generation of the nanotubes were grown in (almost) water free electrolytes. In glycerol electrolytes, the grown tubes have extremely smooth walls and a tube length exceeding 7 micrometer ${ }^{65}$. When the anodization applied using $\mathrm{CH}_{3} \mathrm{COOH}$ electrolytes remarkably small tube diameters could be obtained ${ }^{66}$.

Over the past few years, the application of anodization allow the tube diameters to be adjusted over a wide range from 10 to $250 \mathrm{~nm}$, and the length of nanotube from $100 \mathrm{~nm}$ to several hundred $\mathrm{nm}$ can be grown ${ }^{67,68}$. In aqueous electrolytes, applying anodic potentials in the range of $1-20 \mathrm{~V}$ will produce tubes with diameters between 15 and $100 \mathrm{~nm}^{67,69}$. However, the thickness of the nanotube layers can be influenced by varying the anodization time and the $\mathrm{pH}$ of the electrolyte ${ }^{52,62}$.

\section{Some studies on the titanium oxide nanotube}

Titanium oxide nanotube grown from a $\mathrm{Ti}$ metal and its alloys have attracted wide scientific and technological interest. The electrochemical growth of titanium oxide nanotubes on titanium and its alloys has a history of about 14 years $^{70}$.

Zwilling et $a^{\beta 2}$ first produced nanotubular titanium dioxide on titanium, and the fabrication of titanium oxide nanotube arrays via anodic oxidation of titanium foil in a fluoride-based solution were first reported in 2001 by Grimes and co-workers ${ }^{59}$. After that, many workers applied anodization process to fabrication titanium oxide nanotube in several electrolytes, and characterized the microstructure of the surface by many techniques, such as scanning electron microscopy (SEM), X-ray diffraction (XRD) patterns, and Transmission electron microscope (TEM) 1,13,40,48. Further studies were focused on the effect of the anodization process parameters on the formation and the properties of titanium oxide nanotubes, and how to control and optimize the desired dimension of the oxide nanotube for the desired applications $2,56,57,71-75$. The mechanism of titanium oxide nanotube formation by anodization was discussed by many researchers ${ }^{30,76-78}$.

For biomaterial applications, the electrochemical behavior of titanium covered with titanium oxide nanotube was investigated in simulated body solutions ${ }^{79-83}$. Also, the effects of nanotopographical on the bioactivity of titanium were studied in virto ${ }^{55,70,84-88}$ and in vivo ${ }^{4,89,90}$. Moreover, the growth of nanotube oxide was conducted on binary titanium alloys such as: $\mathrm{Ti}-\mathrm{Zr}{ }^{91,92}, \mathrm{Ti}-\mathrm{Nb}^{93}$, $\mathrm{NiTi}{ }^{94}$, ternary alloys such as: Ti-6Al-4V 5], Ti-6Al$7 \mathrm{Nb}^{6]}$ and $\mathrm{Ti}-13 \mathrm{Nb}-13 \mathrm{Zr}^{7}$, and quarenty alloys like $\mathrm{Ti}-35 \mathrm{Nb}-x \mathrm{Zr}{ }^{7,98}, \mathrm{Ti}-29 \mathrm{Nb}-x \mathrm{Zr}{ }^{7}{ }^{7} \mathrm{ndi}-35 \mathrm{Nb}-5 \mathrm{Ta}-7 \mathrm{Zr}$ alloy ${ }^{5}$.

In the literature, there are many reviews available about titanium nanotubes formation and properties $^{21,56,77,99}$, and its special properties for implant applications $\mathbf{1}^{12,21,100,101}$. But the information about how nanotube oxide can improve the electrochemical properties of titanium as biomaterial is very little, and there are fluctuations in the research results about it. Hence, this project will focus on the titanium oxide nanotube layer prepared by anodization and its role in the change of titanium behavior for biomaterial applications.

\section{The electrochemical behavior of titanium oxide nanotube}

The conditions used to study the electrochemical behavior

The electrochemical corrosion behavior of metals is governed by the interaction between the materials surface and the electrolyte ${ }^{102}$. In the case of nanotube oxide, the effective surface area, determined by the nanotube size ${ }^{103}$, is expected to play an important role in the electrochemical performance of nanotubular titanium and its alloys $^{74}$.

To explain the role of nanotube oxide in changing the electrochemical behavior of titanium, the studies were also conducted in titanium without nanotube oxide, which has a stable, dense oxide layers, consists mainly of $\mathrm{TiO}_{2}{ }^{104}$, thin (about 3-8 $\mathrm{nm}$ in thickness), amorphous, and stoichiometrically defective ${ }^{93}$. 
The electrochemical behavior of titanium oxide nanotube in simulated biological environment was studied using many electrochemical techniques, like open-circuit potential (OCP), electrochemical impedance spectroscopy (EIS), potentiodynamic (PD) and potentiostatic polarization (PS) tests.

The open circuit potential ( or corrosion potential $\left(\mathrm{E}_{\text {corr }}\right)$ ) reflects the composite results of the electrochemical reactions taking place at the electrode and solution interface. Therefore, the variation in the OCP with immersion time can be employed to study the electrochemical processes ${ }^{94}$. From potentiodynamic poalization measuremants, the corrosion potential $\left(\mathrm{E}_{\text {corr }}\right)$ and current $\left(\mathrm{I}_{\text {corr }}\right)$ can be determined, as well as the passivation current $\left(I_{\text {pass }}\right)$. The electrochemical impedance spectroscopy (EIS) is a powerful technique to study the corrosion of metals or alloys. It can provide quantitative evaluation of the corrosion properties of the studied system, which may be difficult to assess using conventional electrochemical measurements such as potentiostatic or potentiodynamic techniques. By appropriate interpretation of the EIS data in conjunction with an equivalent circuit (EC), detailed information on the electrochemical process at the film/solution interface can be disclosed ${ }^{94,53}$.

The simulated biological environments employed in electrochemical studies were involve artificial saliva $^{74}, 0.9 \% \mathrm{NaCl}^{93,96}$, Ringer's solution ${ }^{27,51}$, Hank's solution ${ }^{105}$ or phosphate buffered saline (PBS) $^{106}$.

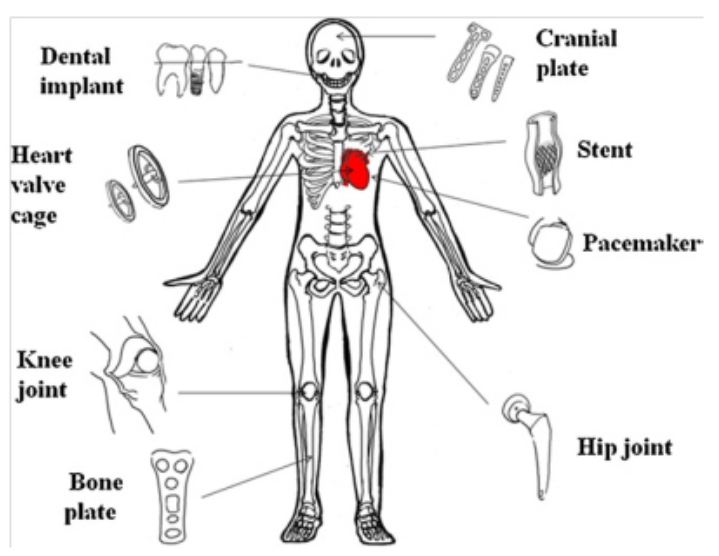

Fig. 1: Biomedical application of titanium and its alloys ${ }^{12}$

\section{Results about electrochemical behavior of titanium oxide nanotube}

Table 1. summaries some recently studies on the electrochemical behavior of titanium and some of its alloys with titanium oxide nanotube prepared by anodization. From the table, the results of most studies indicate that titanium materials with titanium oxide nanotube have a better corrosion resistance in simulated body fluid solutions than that of bare titanium. A smaller current density and higher OCP was observed for titanium oxide nanotube, which means an increase in the stability of titanium surface.

On the other hand, three studies found that the titanium with titanium oxide nanotube exhibited significantly higher corrosion current density and lower corrosion resistance than that of the bare titanium, meaning a lower corrosion resistance than that of titanium.

\section{Discussion of the results}

The difference in the results of the corrosion behavior of titanium oxide nanotube in simulated body fluid solutions can be attributed to the differences in the microstructure of the surface oxide layer, which are affected by several factors.

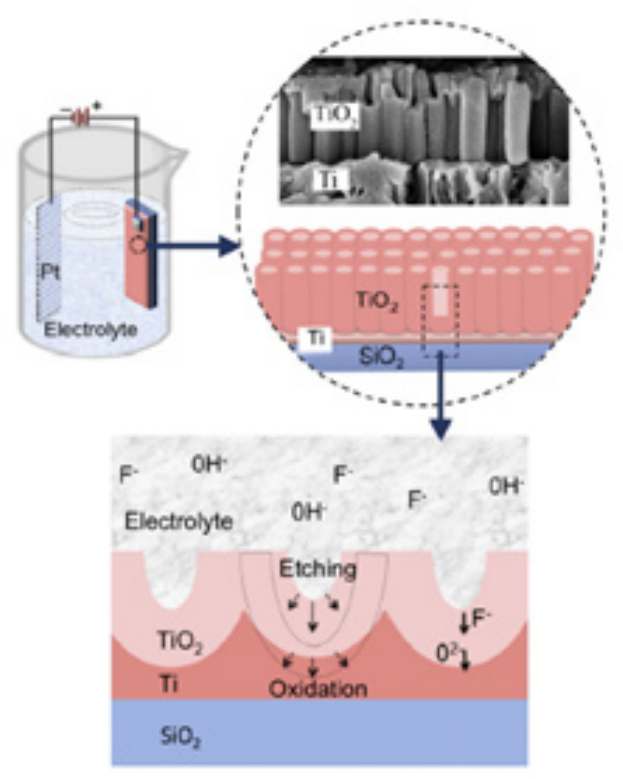

Fig. 2 : The electrochemical cell used for anodization process ${ }^{30}$ 
The diameter and length of the nanotubes and the thickness of the barrier layer can strongly change the electrochemical corrosion behavior of nanotubular titanium ${ }^{52,74}$. The differences in the methods used for preparation of the sample surface before anodization may have some effects on the properties of the oxide nanotube formed. Moreover, an important factor is the properties of the electrolyte employed in the anodization process ${ }^{1,54,96}$.

The EIS of titanium oxide nanotubes indicate the presence of two time constants corresponding to the presence of two interfaces, a highly corrosion resistant barrier layer and the outer nanotubular layer. When Ti exposed to air, a thin and stable oxide several nanometers thick is formed on its surface ${ }^{113}$. In contrast, the anodization process in fluoride solutions results in the growth of uniform arrays atop the titanium surface and a barrier layer separating the nanotubes from the conducting titanium. While the diameter and length of $\mathrm{TiO}_{2}$ nanotube depends on the anodization voltage ${ }^{52,69}$, the thickness of the barrier layer increases with anodizing voltages and approximately equal to the pore radius ${ }^{12}$. In previous work, researchers found that a higher anodizing voltage leads to not only
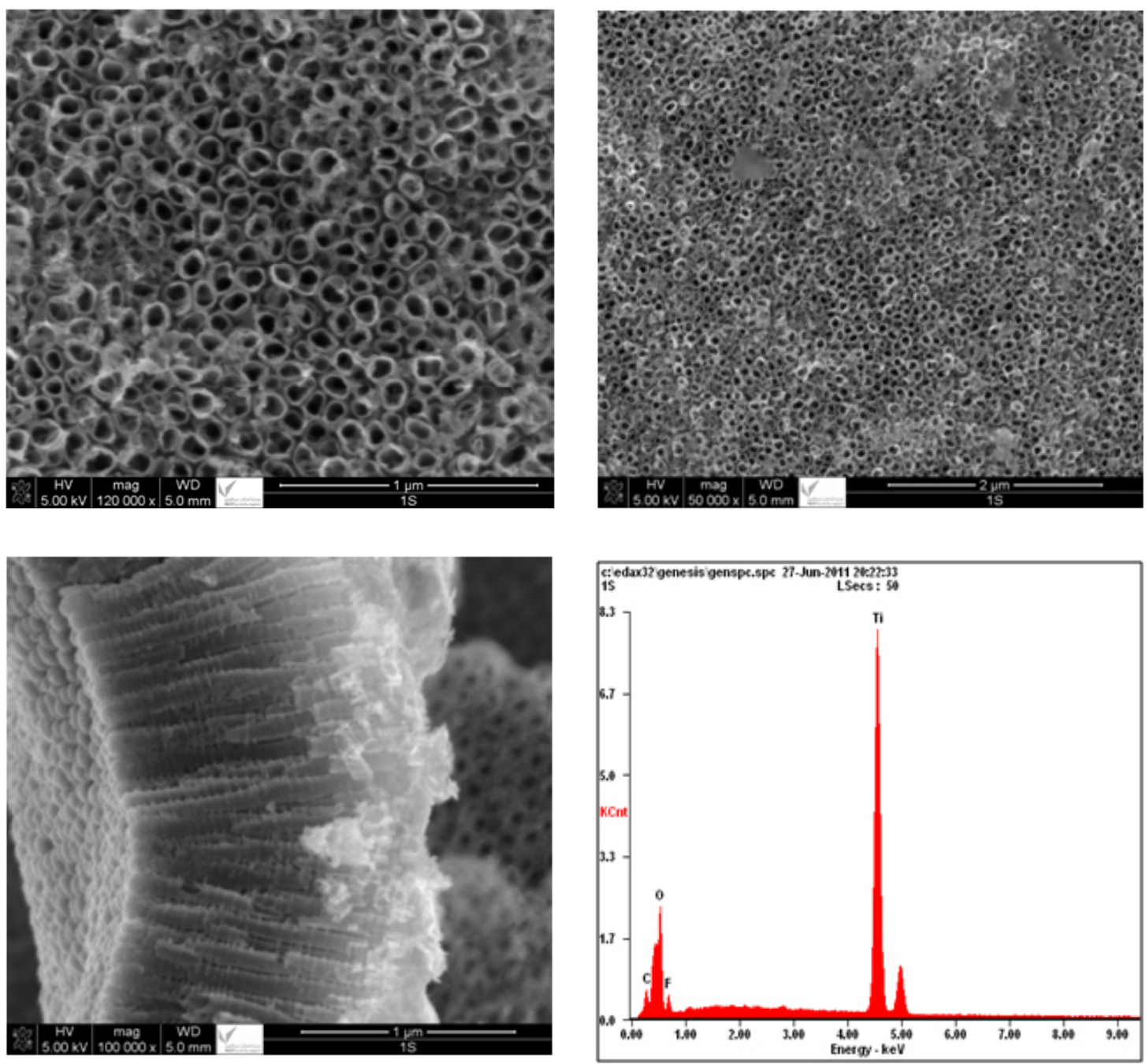

Fig. 3: The SEM images and EDX of titanium oxide nanotubes formed on titanium by anodization in $1 \mathrm{M} \mathrm{Na}_{2} \mathrm{SO}_{4}+0.5 \mathrm{wt}$. $\% \mathrm{NaF}$ at $20 \mathrm{~V}$ for $30 \mathrm{~min}^{53}$ 


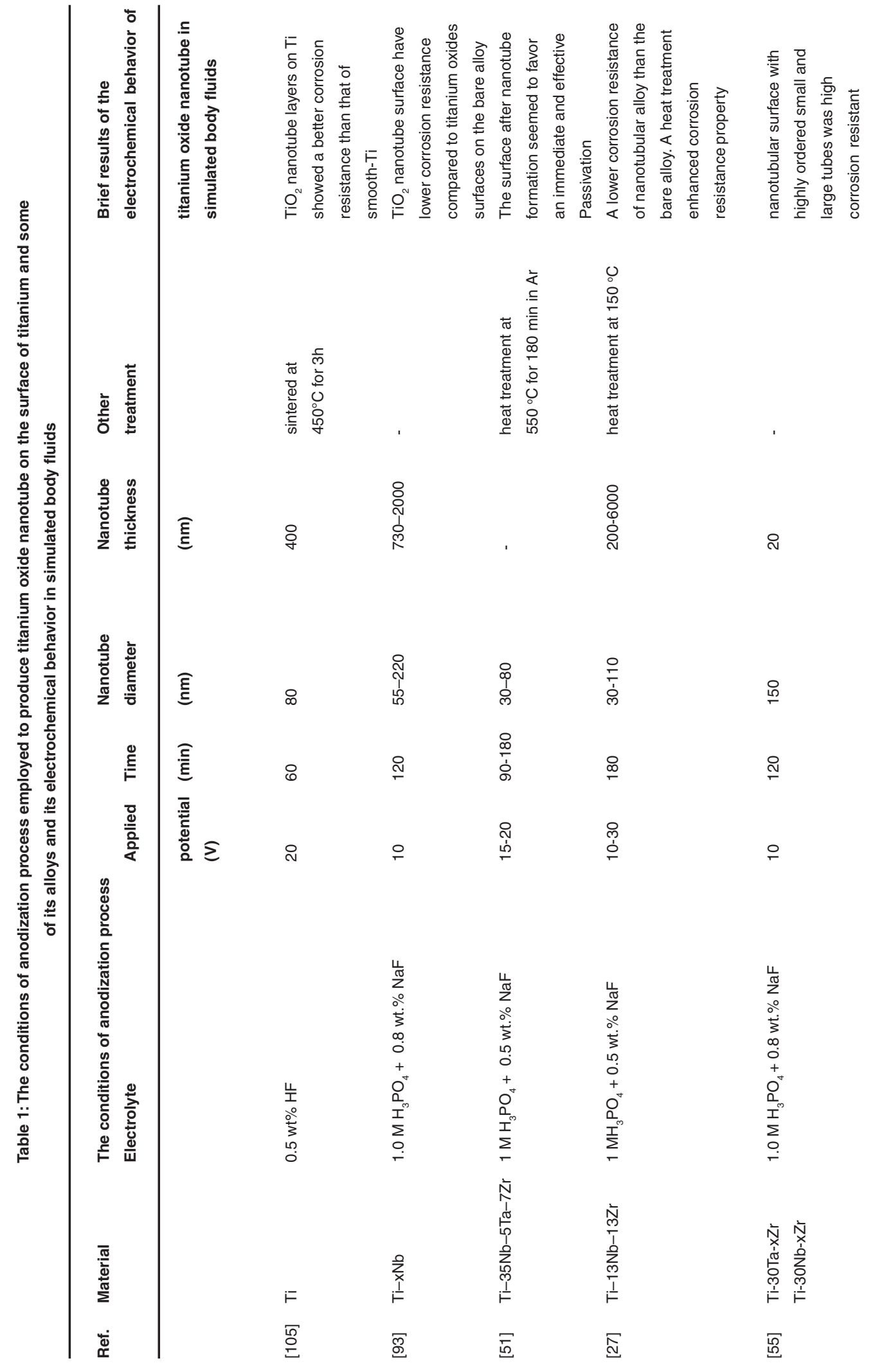



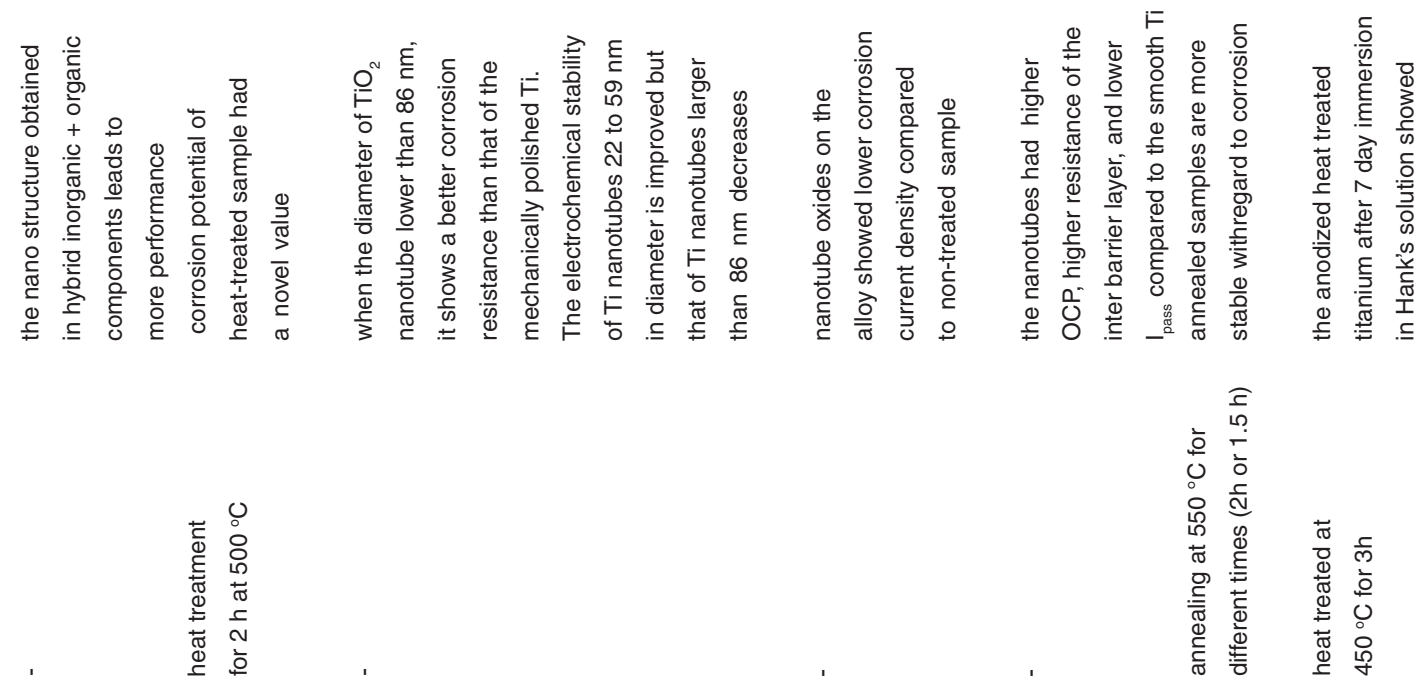

ㄱ

으

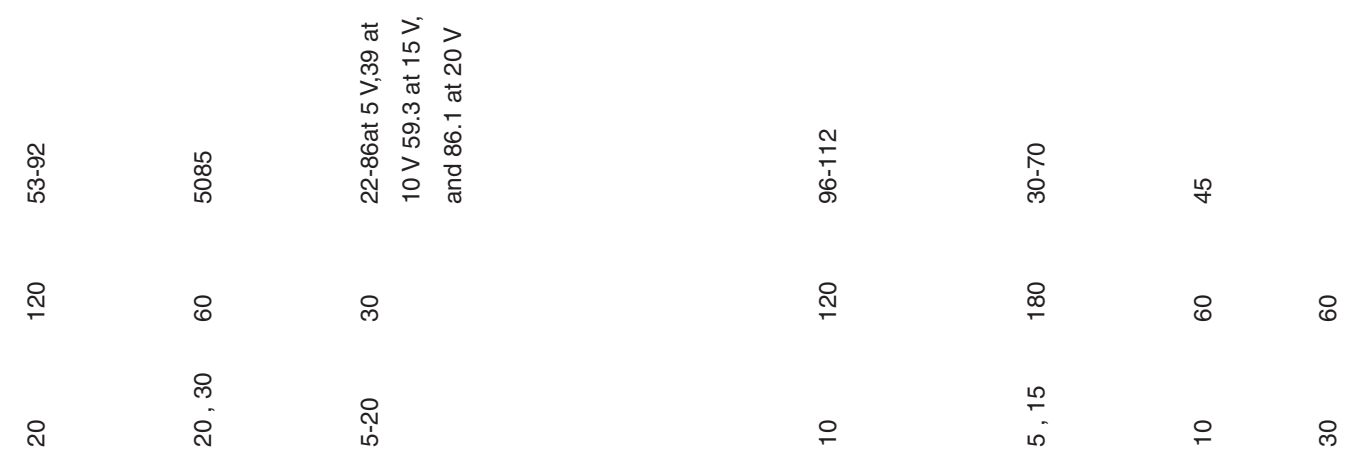
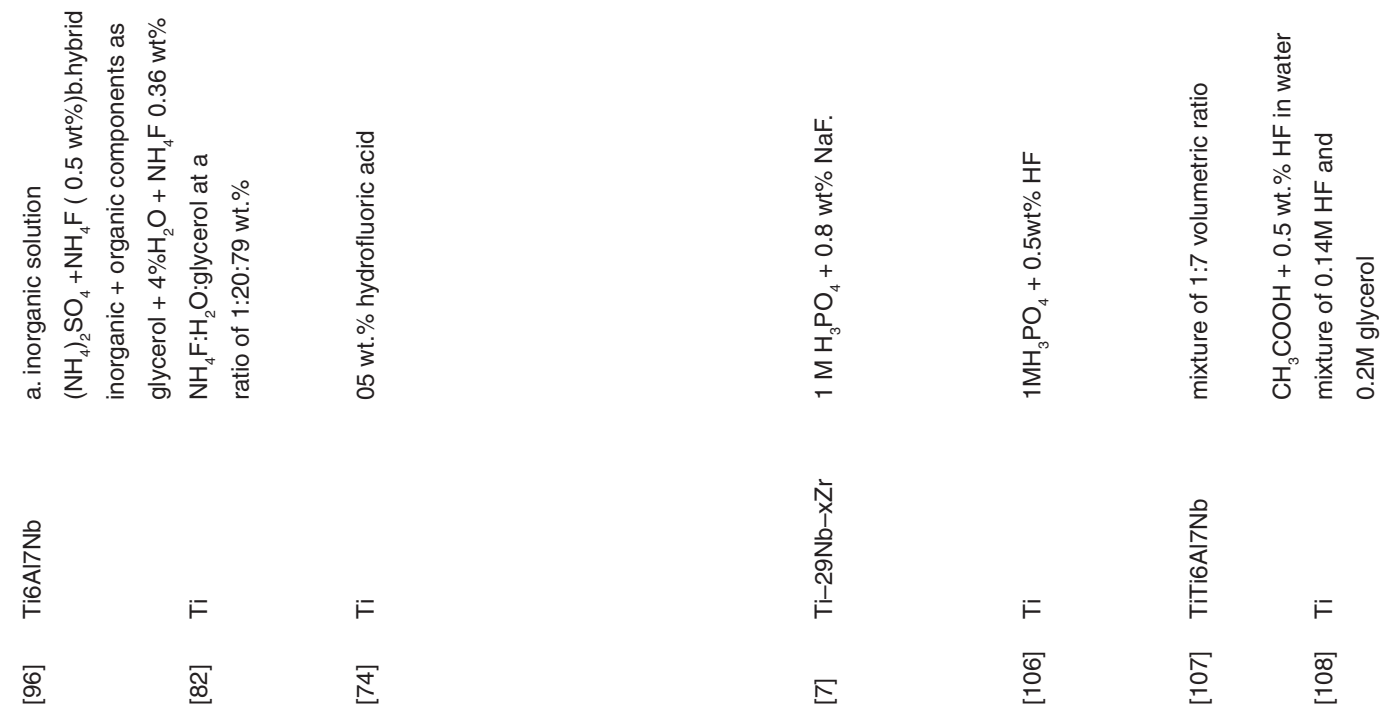

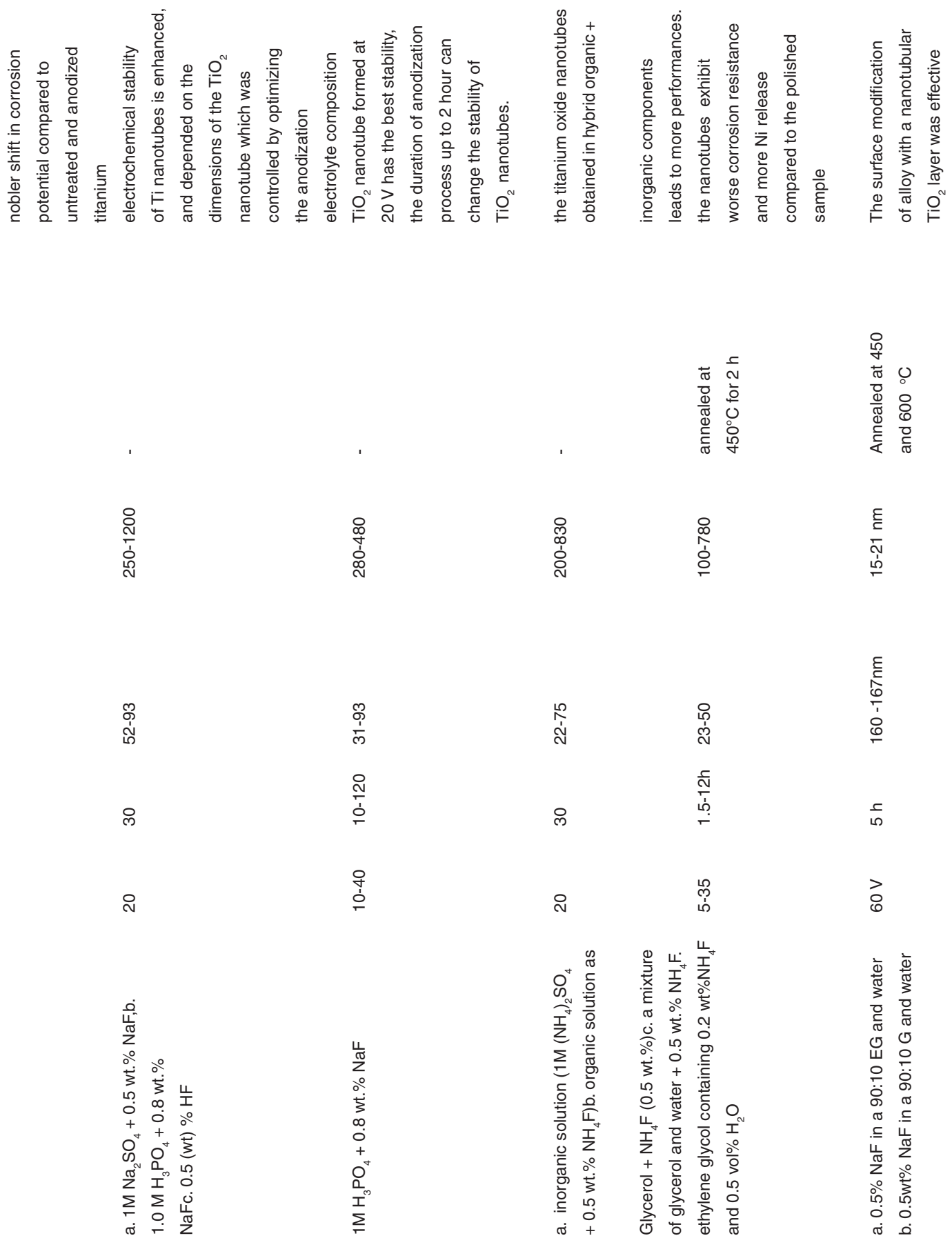

\begin{tabular}{|c|c|c|c|}
\hline$F$ & $F$ & F & $\frac{E}{2}$ \\
\hline & స్త్ర & 跑 & 은 \\
\hline
\end{tabular}



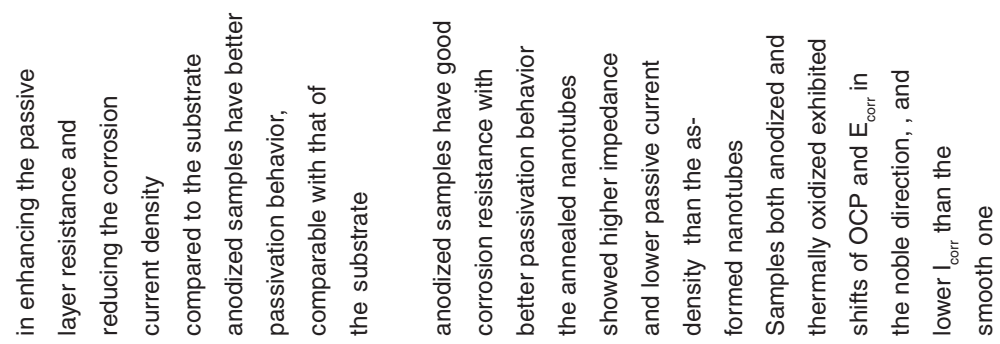

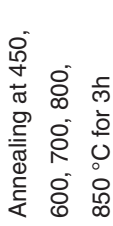
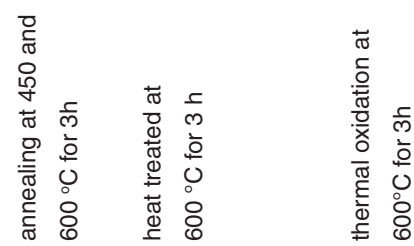

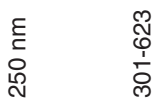

है

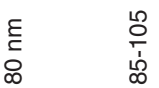

$\subsetneq$

竞

돈

옹

ำ

8
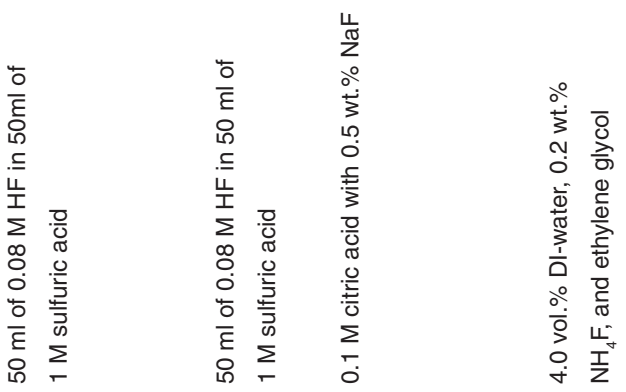

\begin{tabular}{l}
2 \\
\multirow{1}{1}{} \\
$\frac{1}{\alpha}$ \\
1 \\
1
\end{tabular}

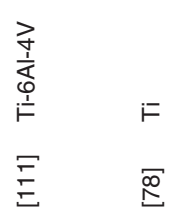

子
$\frac{1}{4}$
$\substack{1 \\ i}$

물

$\stackrel{\infty}{\Xi}$

$\stackrel{N}{\underline{N}}$ 
larger diameter of $\mathrm{TiO}_{2}$ nanotubes, but also thicker barrier layers ${ }^{12,91}$. The thicker inner barrier layer of nanotubes may play a more important role in corrosion resistance of titanium which agrees with the result of EIS ${ }^{105}$.

Many previous studies have shown that the size of titanium oxide nanotube is a key factor to determine its corrosion behavior. When a small diameter $\mathrm{TiO}_{2}$ nanotube grows on pure $\mathrm{Ti}$, a lower corrosion rate is reported, but large nanotubes have an opposite effect ${ }^{106}$. When the diameter of the nanotube is increased, the electrochemical stability increases first and then diminishes when its diameter more than $86 \mathrm{~nm}^{74}$. Improved corrosion resistance of pure titanium when a small nanotube covered it may be ascribed to relatively thick oxide layer formed during anodization at the substrate/nanotube interface. However, the large oxide nanotubes possess a high specific surface area to contact with electrolyte thus beneficial to the diffusion of corrosive ions and corrosion products. The larger nanotubes provide more channels for the electrolyte to reach the barrier layer consequently increasing the chance of the reaction between corrosive ions and titanium oxide $^{91,102}$. This phenomenon was reported by many workers who used nanotubes approximately 150-220 $\mathrm{nm}$ in size in the corrosion tests ${ }^{74,91,93}$.

Some studies reported that the corrosion attack of the nanotubular $\mathrm{Ti}$ is attributed to the collapse of $\mathrm{TiO}_{2}$ nanotubue layer ${ }^{74}$. There is a suggestion that the nanotubes may act as effective channels for the electrolyte to reach the interface. Moreover, Saji and Choe suggested that the lower corrosion resistance of the nanotubular alloy can be associated with the distinctly separated barrier oxide/ concave shaped tube bottom interface ${ }^{27}$.

Another important factor, is the wall between $\mathrm{TiO}_{2}$ nanotubes, which may be influencing its electrochemical stability. The morphology of the corroded titanium oxide nanotubes after the potentiodynamic polarization test showing that the nanotubular structure collapses at the localized corrosion site ${ }^{114}$. The nanotubes forming by anodizing titanium oxide have a dual-layer wall. The inner layer is composed from titanium oxide whereas the outer layer is composed of some form of titanium hydroxide with a relatively low density. Between adjacent nanotubes there is a space, and when corrosive ions in the artificial saliva penetrate, the quick dissolution of the outer layer of $\mathrm{TiO}_{2}$ nanotubes will leading to deposition of phosphate compounds ${ }^{115}$. When the phosphate compounds present in the solution, it will block the small space and retard diffusion of oxygen and/or other dissolved products to and away from the surface of the outer layer, respectively. With reduced oxygen, rebuilding of titanium oxide is slowed, causing further dissolution of the wall between adjacent nanotubes and eventually collapse of the wall ${ }^{74}$.

Thus, optimized parameters of the anodization process to form nanotube oxide, such as anodization potential, nature of the electrolyte, concentration of the electrolyte, duration of anodization, temperature and the potential sweep rate is critical in achieving the desirable size and shape of the self-ordered nanotubes ${ }^{27,51,55}$.

Formore improvement in the electrochemical corrosion behavior of titanium oxide nanotube, many workers suggested that suitable heat treatment processes of oxide nanotube can provide the required bioactivity and chemical stability which is important in biocompatibility point of view for potential implant applications ${ }^{27,82}$.

The structure of the grown oxide nanotube can be amorphous or crystalline, strongly dependent on the electrochemical parameters of the anodization process, such as the applied potential, the time of anodization, or the sweep rate of the potential. For example, at low voltages (below $20 \mathrm{~V}$ ), the structure of the oxide films on Ti has typically been reported to be amorphous, and crystallization to take place at higher voltages ${ }^{116}$. Moreover, depending on the anodizing conditions the crystal structure can be anatase, a mixture of anatase and rutile, or rutile ${ }^{117}$.

Many of the studies confirm that the thermal treatments resulting in an improvement of the adhesion of nanotubes to the titanium substrate require temperatures above $400{ }^{\circ} \mathrm{C}^{118,119}$. At such temperatures, structural changes lead to a crystalline titanium dioxide ${ }^{118}$. These structural 
changes can enhance the mechanical stability of the porous anodic layers without changing the diameter of the oxide nanotubes. Thus, an appropriate heat treatment can render titanium oxide nanotubes.

After nanotubes were annealed, there was a significant decrease in the passive current density and corrosion current density $27,120,121$, because the anatase nanotubes had a stable phase compared to the amorphous nanotubes ${ }^{120,121}$. Furthermore, the standard potential $E^{\circ}$ of anatase nanotubes was lower than that of amorphous one, which can be attributed to the surface area decrease because the pores became smaller or were closed after annealing ${ }^{120}$.

The role of titanium oxide nanotube on the improve the osseointegration of biomaterials

Recently, many of the researches focus on the biomaterials surface, aimed to understanding the fundamental processes at the interface between the implant surfaces and surrounding living tissues, that the human biology and nature should be considered in the design of functionalized biomaterials ${ }^{122}$.

When the biomaterial implanted in soft tissue, it induces a cell-mediated inflammatory response and fibrotic encapsulation ${ }^{123}$, which means an inflammatory processes immediately following the implantation, that are inherently present at biomaterials surfaces during wound healing events ${ }^{18}$.

During early stage wound healing produce nitric oxide (NO), which is a key indicator of pro-inflammatory signal transduction in the inflammatory response and antimicrobial defense ${ }^{124}$. The inflammatory cells generate superoxide anion and reactive oxygen intermediates ${ }^{125}$. Further degradation may yield hydroxyl radicals, singlet oxygen, and hydrogen peroxide. Thus, the ability of a biomaterial to interact with inflammatory cells, and reactive oxygen and nitrogen species may be relevant for the host response. Results of titanium oxide nanotubes were shown to reduce the levels of the pro-inflammatory compared with a planar $\mathrm{TiO}_{2}$ control surface, which suggests that the titanium oxide nanotubes elicit a favorable response in soft tissues. This may be due to the increased catalytic oxide surface area of the $\mathrm{TiO}_{2}$ nanotubes ${ }^{4,48}$. The
$\mathrm{TiO}_{2}$ nanotubes possess an empty volume for filling with bioactivating species and provide an interface suitable for anchoring connective tissue ${ }^{84}$.

The results of many studies conducted to evaluate the nanomaterials chemistry suggest that increased bone cell functions may be independent of the bulk materials chemistry but rather rely on the degree of the nanostructured surface roughness ${ }^{126-128}$.

Titanium oxide nanotubes offer an empty volume that can be filled with bioactive species and provide an interface suitable for anchoring connective tissue. Results indicated that the $\mathrm{TiO}_{2}$ nanotubes enhance the process of apatite formation as compared to that on a common native oxide layer on titanium ${ }^{84,129}$, which considered to be an essential step for the bone-binding ability of biomaterials to the living bone. The incorporating of calcium phosphate crystals into the nanotubes can result in better adhesion of the coating to the substrate, and more osseointegration ${ }^{17}$.

To further improve the bioactivity and biocompatibility of titanium, various types of surface modification methods have been explored to enhance hydroxyapatite formation ${ }^{130}$. The nanotubular structure increased the surface area and also more 'in-between-nanotube path-ways for fluid'129. The faster and better nucleation on the nanotubes might be caused by the fact that the ions have better access to the surface when it is nanotubular, they can diffuse into the channels and form nuclei very homogeneously all over the walls, whereas the apatite growth on flat $\mathrm{TiO}_{2}$ proceeds in a more heterogeneous, mushroom-like manner ${ }^{90}$. Thus, the increased surface area of the titanium oxide nanotubes is useful for accelerated bone growth in orthopedic/dental applications ${ }^{129}$. Balasundaram and Webster suggest that nanophase has ability to mimic the dimensions of the constituents and components in natural bone-like proteins and hydroxyapatite ${ }^{8}$.

The annealing of the amorphous nanotube layers to anatase or a mixture of anatase and rutile will enhance the apatite formation ${ }^{84}$. The proper heat treatment introduction of anatase phase form of titanium oxide in the nanotubes can further improve the biological activity ${ }^{130}$. 


\section{CONCLUSION}

When titanium and its alloys subject to anodization in suitable manner, the formation of $\mathrm{TiO}_{2}$ nanotube will occure. The electrochemical behavior of titanium oxide nanotube in simulated body fluids depends on its morphology and surface properties. When titanium oxide nanotube formed by anodization, these surface properties are depending strongly on two factors, The first is the parameters of anodization process, i.e. applied potential, duration of anodization and the method employed to prepare the sample surface. The second is the conditions of the electrolyte employed in the anodization cell, i.e. composition, fluoride ion concentration, temperature, $\mathrm{pH}$ and water content in the electrolyte. Thus, all these factors must be taking into account to produce titanium oxide nanotube with desired properties that needed for special application.

\section{REFERENCES}

1. Deen, K.M.; Farooq, A.; Raza, M.A.; Haider, W. Electrochim. Acta 2014, 117, 329

2. Indira, K.; Ningshen, S.; Kamachi Mudali, U.; Rajendran, N. Mater. Char. 2012, 71, 58

3. Fujishima, A.; Rao, T.N.; Tryk, D.A. J. Photochem. Photobiol. C: Photochem. Rev. 2000, 1, 1

4. Smith, G.C.; Chamberlain, L.; Faxius, L.; Johnston, G.W.; Jin, S.; Bjursten, L.M. Acta Biomaterialia 2011, 7, 3209

5. Park, K.H.; Heo, S.J.; Koak, J.Y.; Kim, S.K.; Lee, J.B., Kim, S.H. J. Oral. Rehabil. 2007, 34, 517

6. Lai, Y.; Zhuang, H.; Sun, L.; Chen, Z.; Lin, C. Electrochim. Acta 2009, 54, 6536

7. Kim, J.; Kim, B.; Lee, K.; Choe, H.; Ko, Y. J of Nanosci. and Nanotech. 2011, 11, 1636

8. Balasundaram, G.; Webster, T.J. J Mater. Chem. 2006, 16, 3737

9. Patan, M.; Shah, T.; Sahin, M. Conf Proc IEEE Eng. Med. Biol. Soc. 2006, 1, 890

10. Selvakumaran, J., Keddie, J.L.; Ewins, D.J.; Hughes, M.P. J Mater. Sci. Mater. Med. 2008, 19,143

11. Dai, Z.; Fang, M.; Bao, J.; Wang, H.; Lu, T. Anal. Chim. Acta. 2007, 591, 195

12. Tan, A.W.; Pingguan-Murphy, B.; Ahmad, R.; Akbar, S.A. Ceramics International 2012, 38, 4421

13. Gordin, D. M.; Gloriant, T.; Nemtoi, G.; Chelariu, R.; Aelenei, N.; Guillou, A.; Ansel, D. Mater. Lett. 2005, 59, 2936

14. Williams, D.F. Biomaterials 2008, 29, 2941

15. Kasemo, B. J. Prosthet. Dent. 1983, 49, 832

16. McCafferty, E.; Wightman, J.P. Appl. Surf. Sci. 1999, 143, 92

17. Roguska, A.; Pisarek, M.; Andrzejczuk, M.;
Dolata, M.; Lewandowska, M.; Janik-Czachor, M. Mater. Sci. and Eng. C 2011, 31, 906

18. Tengvall, P. ; Elwing, H.; Sjoqvist, L.; Lundstrom, I.; Bjursten, L.M. Biomaterials 1989, 10, 118

19. Suzuki, R.; Frangos, J.A. Clin. Orthop. Relat. Res. 2000, 372, 280

20. Suzuki, R.; Muyco, J.; McKittrick, J.; Frangos, J.A. J. Biomed. Mater. Res. A 2003, 66, 396

21. Minagar, S.; Berndt, C.C.; Wang, J.; Ivanova, E.; Wen, C. Acta Biomaterialia 2012, 8, 2875

22. Liu, X.; Chu, P.; Ding, C. Mater. Sci. Eng. R. 2004, 47, 49

23. Duan, K.; Wang, R. J. Mater. Chem. 2006, 16, 2309

24. Mohammed, M.T.; Khan, Z.A.; Siddiquee, A.N. Procedia Mater. Sci. 2014, 6, 1610

25. Webster, T.J.; Ergun, C.; Doremus, R.H.; Siegel, R.W.; Bizios, R. Biomaterials 2000 , 21, 1803

26. Khan, F. H. Orient. J. Chem. 2013, 29, 1399, DOI:http://dx.doi.org/10.13005/ojc/290415

27. Saji, V.S.; Choe, H.C. Corr. Sci. 2009, 51, 1658

28. Saji, V.S.; Choe, H.C.; Brantley, W.A. J. Mater. Sci. 2009, 44, 3975

29. Webster, T.J.; Schandler, L.S.; Siegel, R.W.; Bizios, R. Tissue Eng. 2001, 7, 291

30. Butail, G.; Ganesan, P.G.; Raddiar, M.; Teki, R.; Ravishankar, N.; Duquette, D.J.; Ramanath, G. Thin Solid Films 2011, 519, 1821

31. Jeong, Y.H.; Lee, K.; Choe, H.C.; Ko, Y.M.; Brantley, W.A. Thin Solid Films 2009, 517, 5365

32. Zwilling, V.; Aucounturier, M.; Darque-Ceretti, 
E. Electrochim. Acta 1999, 45, 921

33. Simchi, A.; Tamjid, E.; Pishbin, F.; Boccaccini, A.R. Nanomedicine: Nanotechnology, Biology, and Medicine 2011, 7, 22

34. Xiao, X.; Yu, J.; Tang, H.; Mao, D.; Wang, C.; Liu, R. Mater. Chem. and Phys. 2013, 138, 695

35. Popat, K.C.; Leoni, L.; Grimes, C.A.; Desai, T.A. Biomaterials 2007, 28, 3188

36. Fujishima, A.; Zhang, X.; Tryk, D.A. Surf. Sci. Rep. 2008, 63, 515

37. Park, J.H.; Kim, S.; Bard, A.J. Nano Lett. 2006, 6, 24

38. Varshney, G.; Kanel, S.R.; Kempisty, D.M.; Varshney, V.; Agrawal, A.; Sahle-Demessie, E.; Varma, R.S.; Nadagouda, M.N. Coordination Chemistry Reviews 2016, 306, 43

39. Kim, K.S.; Baek, W.H.; Kim, J.M.; Yoon, T.S.; Lee, H.H.; Kang, C.J. Sensors 2010, 10 , 765

40. Pavasupree, S.; Suzuki, Y.; Art, S.P.; Yoshikawa, S. Sci. Technol. Adv. Mater. 2005, 6, 224

41. Jakubowicz, J. Electrochem. Commun. 2008, 10,735

42. Miyauchi, M.; Tokudome, H. J. Mater. Chem. 2007, 17, 2095

43. Nandanwar, R.; Singh, P.; Syed, F. F.; Haque, F. Z. Orient. J. Chem., 2014, 30, 1577, DOI : http://dx.doi.org/10.13005/ojc/300417

44. Miao, L.; Tanemura, S.; Toh, S.; Kaneko, K.; Tanemura, M. Appl. Surf. Sci. 2004, 238, 175

45. Tesfamichael, T.; Motta, N.; Bostrom, T.; Bell, J.M. Appl. Surf. Sci. 2007, 253, 4853

46. Komarov, F.F.; Vlasukova, L.A.; Milchanin, O.M.; Gaiduk, P.I.; Yuvchenko, V.N.; Grechnyi, S.S. Vacuum 2005, 78, 361

47. Yoriya, S.; Paulose, M.; Varghese, O.K.; Mor, G.K.; Grimes, C.A. J. Phys. Chem. C 2007, 111, 13770

48. Oh, S.; Daraio, C.; Chen, L.H.; Pisanic, T.R.; Finones, R.R.; Jin, S. J. Biomed. Mater. Res. A 2006, 78, 97

49. Liu, R.; Yang, ; Qiang, L.S.; Wu, J.F. Thin Solid Films 2011, 519, 6459

50. Tsuchiya, H.; Macak, J.M.; Ghicov, A.; Taveira, L.; Schmuki, P. Corros. Sci. 2005, 47, 3324

51. Saji, V.S.; Choe, H.C.; Brantley, W.A. Acta Biomaterialia 2009, 5, 2303

52. Al-Swayih, A.A. J. of American Sci. 2014, 10,
165

53. Al-Mobarak, N.A.; Al-Swayih, A.A. Int. J. Electrochem. Sci. 2014, 9, 32

54. Alswayih, A.A. Life Science J. 2014, 11, 52

55. Choe, H.C.; Kim, W.G.; Jeong, Y.H. Sur. and Coat. Tech. 2010, 205, S305

56. Macak, J.M.;Tsuchiya, H.; Ghicov, A.; Yasuda, K.; Hahn, R.; Bauer, S.; Schmuki, P. Current Opinion in Solid State and Materials Science 2007, 11, 3

57. Rafieerad, A.R.; Bushroa, A.R.; Zalnezhad, E.; Sarraf, M.; Basirun, W.J.; Baradaran, S.; Nasiri-Tabrizi, B. Ceramics Internationa/2015, 41, 10844

58. Zwilling, V.; Ceretti, E.D.; Forveille, A.B.; David, D.; Perrin, M.Y.; Aucouturier, M. Surf. Interface Anal. 1999, 27, 629

59. Gong, D.; Grimes, C.A.; Varghese, O.K.; Chen, Z.; Dickey, E.C. J. Mater. Res. 2001, 16, 3331

60. Beranek, R.; Hildebrand, H.; Schmuki, P. Electrochem. Solid-State Lett. 2003, 6, B12

61. Macak, J.M.; Sirotna, K.; Schmuki, P. Electrochim. Acta 2005, 50, 3679

62. Macak, J.M.; Tsuchiya, H.; Schmuki, P. Angew. Chem. 2005, 44, 2100

63. Taveira, L.V.; Macak, J.M.; Tsuchiya, H.; Dick, L.F.P.; Schmuki, P. J. Electrochem. Soc. 2005, 152, B405

64. Ghicov, A.; Tsuchiya, H.; Macak, J.M.; Schmuki, P. Electrochem. Commun. 2005, 7, 505.

65. Macak, J.M.; Tsuchiya, H.; Taveira, L.; Aldabergerova, S.; Schmuki, P. Angew. Chem. Int. Ed. 2005, 44, 7463

66. Tsuchiya, H.; Macak, J.M.; Taveira, L.; Balaur, E.; Ghicov, A.; Sirotna, K.; Schmuki, P. Electrochem. Commun. 2005, 7, 576

67. Macak, J.M.; Tsuchiya1, H.; Ghicov, A.; Yasuda, K.; Hahn, R.; Bauer, S.; Schmuki, P. Curr. Opin. Solid State Mater. Sci. 2007, 11, 3

68. Ghicov, A.; Schmuki, P. Chem. Comm. 2009, 20, 2791

69. Bauer, S.; Kleber, S.; Schmuki, P. Electrochem. Commun. 2006, 8, 1321

70. Roman, I.; Trusca, R.D.; Soare, M.L.; Fratila, C.; Krasicka-Cydzik, E.; Stan, M.S.; Dinischiotu, A. Mater. Sci. and Eng. C 2014, 37, 374

71. Cai, Q.; Yang, L.; Yu, Y. Thin Solid Films 2006, 
515, 1802

72. Xie, Z.B.; Blackwood, D.J. Electrochim. Acta 2010, 56, 905

73. Omidvar, H.; Goodarzi, S.; Seif, A.; Azadmehr, A.R. Superlattices and Microstructures 2011 , 50,26

74. Liu, C.; Wang, Y.; Wang, M.; Huang, W.; Chu, P.K. Sur. and Coat. Tech. 2011, 206, 63

75. Palmas, S.; Da Pozzo, A.; Delogu, F.; Mascia, M.; Vacca, A.; Guisbiers, G. J. of Power Sources 2012, 204, 265

76. Mizukoshi, Y.; Ohtsu, N.; Masahashi, N. App. Sur. Sci. 2013, 283, 1018

77. Regonini, D.; Bowen, C.R.; Jaroenworaluck, A.; Stevens, R. Mater. Sci. and Eng. R 2013, 74, 377

78. Munirathinam, B.; Neelakantan, L. Mater. Sci. and Eng. C 2015, 49, 567

79. Mazzarolo, A.; Curioni, M.; Vicenzo, A.; Skeldon, P.; Thompson, G.E. Electrochim. Acta 2012, 75, 288

80. Prosini, P.P.; Cento, C.; Pozio, A. Electrochim. Acta 2013, 111, 120

81. Garbacz, H.; Pisarek, M.; Kurzyd³owski, K.J. Biomolecular Eng. 2007, 24, 559

82. Park, H.H.; Park, I.S.; Kim, K.S.; Jeon, W.Y.; Park, B.K.; Kim, H.S.; Bae, T.S.; Lee, M.H. Electrochim. Acta 2010, 55, 6109

83. Hsu, H.C.; Wu, S.C.; Hsu, S.K.; Chang, Y.C.; Ho, W.F. Mater. Charact. 2015, 100, 170

84. Kodama, A.; Bauer, S.; Komatsu, A.; Asoh, H.; Ono, S.; Schmuki, P. Acta Biomaterialia 2009, 5, 2322

85. Yavari, S.A.; Chai, Y.C.; Böttger, A.J.; Wauthle, R.; Schrooten, J.; Weinans, H.; Zadpoor, A.A. Mater. Sci. and Eng. C 2015, 51, 132

86. Liu, X.; Chu, P.K.; Ding, C. Mater. Sci. and Eng. $R$ 2010, 70, 275

87. Hao, Y.Q.; Li, S.J.; Hao, Y.L.; Zhao, Y.K.; Ai, H.J. App. Sur. Sci. 2013, 268, 44

88. Parcharoen, Y.; Kajitvichyanukul, P.; Sirivisoot, S.; Termsuksawad, P. App. Sur. Sci. 2014, 311, 54

89. Narayanan, R.; Lee, H.J.; Kwon, T.Y.; Kim, K.H. Mater. Chem. and Phys. 2011, 125 , 510

90. Kunze, J.; Muller, L.; Macak, J.M.; Greil, P.; Schmuki, P.; Muller, F.A. Electrochim. Acta 2008, 53, 6995

91. Kim, W.G.; Choe, H.C. Trans. Nonferrous Met.
Soc. China 2009, 19, 1005

92. Grigorescu, S.; Ungureanu, C.; Kirchgeorg, R.; Schmuki, P.; Demetrescu, I. App. Sur. Sci. 2013, 270, 190

93. Jang, S.H.; Choe, H.C.; Ko, Y.M.; Brantley, W.A. Thin Solid Films 2009, 517, 5038

94. Hu, T.; Xin, Y.C.; Wu, S.L.; Chu, C.L.; Lu, J.; Guan, L.; Chen, H.M.; Hung, T.F.; Yeung, K.W.K.; Chu, Paul K. Mater. Chem. and Phys. 2011, 126, 102

95. Benea, L.; Danaila, E.M.; Mardare, M.; Celis, J.P. Corr. Sci. 2014, 80, 331

96. Mindroiu, M.; Pirvu, C.; Ion, R.; Demetrescu, I. Electrochim. Acta 2010, 56, 193

97. Jeong, Y.H.; Choe, H.C.; Brantley, W.A. Thin Solid Films 2011, 519, 4668

98. Jeong, Y.H.; Choe, H.C.; Brantley, W.A. App. Sur. Sci. 2012, 258, 2129

99. Kowalski, D.; Kim, D.; Schmuki, P. Nano Today 2013, 8, 235

100. Hanawa, T. Japanese Dental Science Review 2010, 46, 93

101. Yang, B.; Ng, C.K.; Fung, M.K.; Ling, C.C.; Djurisic, A.B.; Fung, S. Mater. Chem. and Phys. 2011, 130, 1227

102. Balamurugan, A.; Rajeswari, S.; Balossier, G. Mater. Corros. 2008, 59, 855

103. Balaur, E.; Macak, J.M.; Tsuchiya, H.; Schmuki, P. J. Mater. Chem. 2005, 15, 4488

104. Feng, X.J.; Macak, J.M.; Albu, S.P.; Schmuki, P. Acta Biomaterialia 2008, 4, 318

105. Yu, W.; Qiu, J.; Xu, L.; Zhang, F. Biomed. Mater. 2009, 4, 065012

106. Yu, W.; Qiu, J.; Zhang, F. Colloids and Surfaces 2011, B84, 400

107. Mazare, A.; Dilea, M.; Ionita, D.; Titorencu, I.; Trusca, V.; Vasile, E. Bioelectrochemistry 2012, 87, 124

108. Indira, K.; Mudali, U.K.; Rajendran, N. Ceramics International 2013, 39, 959

109. Hang, R.; Liu, Y.; Liu, S.; Bai, L.; Gao, A.; Zhang, X.; Huang, X.; Tang, B.; Chu, P.K. Corr. Sci. 2016, 103, 173

110. Mohan, L.; Anandan, C.; Rajendran, N. Mater. Sci. and Eng. C 2015, 50, 394

111. Mohan, L.; Anandan, C.; Rajendran, N. Electrochim. Acta 2015, 155, 411

112. Grotberg, J.; Hamlekhan, A.; Butt, A.; Patel, S.; Royhman, D.; Shokuhfar, T.; Sukotjo, C.; Takoudis, C.; Mathew, M.T. Mater. Sci. and 
Eng. C 2016, 59, 677

113. Hiromoto, S.; Hanawa, T.; Asami, K. Biomaterials 2004, 25, 979

114. Mariano, N.A.; Oliveira, R.G.; Fernandes, M.A. Revista Materia 2009, 14, 878

115. Sue, Z.X.; Zhou, W.Z. J. Mater. Chem. 2009, 19,2301

116. Schultze, J.W.; Lohrengel, M.M.; Ross, D. Electrochim. Acta 1983, 28, 973

117. Marchenoir, J.C.; Loup, J.P.; Masson, J. Thin Solid Films 1980, 66, 357

118. Aldabergenova, S.B.; Ghicov, A.; Albu, S.; Macak, J.M.; Schmuki, P. J. Non-Cryst. Solids 2008, 354, 2190.

119. Roguska, A.; Kudelski, A.; Pisarek, M.; Lewandowska, M.; Dolata, M.; Janik-Czachor, M. J. Raman Spectrosc. 2009, 40, 1652

120. Souza, M.E.P.; Ballester, M.; Freire, C.M.A. Surf. Coat Technol. 2007, 201, 7775

121. Guleryuz, H.; Cimenoglu, H. Biomaterials 2004, 25, 3325
122. Leeuwenburgh, S.C.G.; Jansen, J.A.; Malda, J.; Wouter, A.D.; Rouwkema, J.; Van Blitterswijk, C.A.; Kirkpatrick, C.J.; Williams, D.F. Biomaterials 2008, 29, 3047

123. Hunt, J.A.; Williams, D.F. Biomaterials 1995, 16, 167

124. Radi, R. Proc. Natl. Acad. Sci. USA 2004, 101, 4003

125. Tan, K.S.; Qian, L.; Rosado, R.; Flood, P.M.; Cooper, L.F. Biomaterials 2006, 27, 5170

126. Webster, T.J.; Ejiofor, J.U. Biomaterials 2004, 25, 4731

127. Webster, T.J.; Smith, T.A. J. Biomed. Mater. Res. 2005, 74A, 677

128. Manjubala, I. ; Scheler, S.; Bossert, J.; Jandt, K.D. Acta Biomater. 2006, 2, 75

129. Oh, S.; Jin, S. Mater. Sci. Eng. C 2006, 26, 1301

130. Uchida, M.; Kim, H.M.; Kokubo, T.; Fujibayashi, S.; Nakamura, T. J. Biomed. Mater. Res. 2003, 64, 164 